\title{
The influence of $\mathrm{La}_{2} \mathrm{O}_{3}$-doping on structural, surface and catalytic properties of nano-sized cobalt-manganese mixed oxides
}

\author{
Abdelrahman A. Badawy ${ }^{1}$ - Shaimaa M. Ibrahim ${ }^{2,3}$
}

Received: 20 August 2015/Accepted: 11 December 2015/Published online: 3 March 2016

(C) The Author(s) 2016. This article is published with open access at Springerlink.com

\begin{abstract}
Structural, textural and catalytic activity of CoO- $\mathrm{Mn}_{2} \mathrm{O}_{3}$ system as being influenced by $\mathrm{La}_{2} \mathrm{O}_{3}$-doping $(0.75-3 \mathrm{~mol} \%)$ and calcination temperatures $\left(300-500{ }^{\circ} \mathrm{C}\right)$ were investigated. The techniques employed were $\mathrm{XRD}$, $\mathrm{N}_{2}$-adsorption-desoprtion at $-196{ }^{\circ} \mathrm{C}$, EDX and catalysis of $\mathrm{H}_{2} \mathrm{O}_{2}$-decomposition in aqueous solution at $30-50{ }^{\circ} \mathrm{C}$. The results revealed that the investigated system consisted of nano-sized $\mathrm{Co}_{2} \mathrm{MnO}_{4}$ as a major phase together with unreacted portion of $\mathrm{Co}_{3} \mathrm{O}_{4}$ and $\gamma-\mathrm{Mn}_{3} \mathrm{O}_{4}$. Doping with the smallest amount of $\mathrm{La}_{2} \mathrm{O}_{3}$ greatly increased the surface molar ratio of $\mathrm{Mn} / \mathrm{Co}(88 \%)$ for the solid calcined at $500{ }^{\circ} \mathrm{C}$ with subsequent increase of the catalytic activity more than 12 -fold for solids calcined at $500{ }^{\circ} \mathrm{C}$. The increase of $\mathrm{La}_{2} \mathrm{O}_{3}$-dopant above $0.75 \mathrm{~mol} \%$ decreased progressively the surface molar ratio of $\mathrm{Mn} / \mathrm{Co}$ with subsequent decrease in the catalytic activity which still measured higher values than that measured for the un-doped catalyst.
\end{abstract}

Keywords Cobalt manganite $\cdot \mathrm{La}_{2} \mathrm{O}_{3}$-dopant . Coprecipitation - Catalytic decomposition of $\mathrm{H}_{2} \mathrm{O}_{2}$

Abdelrahman A. Badawy

aabadawy107@yahoo.com

1 Physical Chemistry Department, National Research Centre, Dokki, Cairo, Egypt

2 Chemistry Department, Faculty of Education, Ain Shams University, Cairo, Egypt

3 Present Address: Department of Chemistry, Faculty of Science, Qassim University, Buraidah, Saudi Arabia

\section{Introduction}

Manganese oxides are reported to be considered as environment-friendly materials. $\mathrm{MnO}_{2}$ and $\mathrm{Mn}_{3} \mathrm{O}_{4}$ were found to be active and stable catalysts for the combustion of organic compounds $[1,2]$.

Nanocrystalline manganese oxide powders were synthesized in previous study by an inert gas condensation technique [3]. The manganese oxide, which is prepared, is a mixture of $\mathrm{MnO}$ and $\mathrm{Mn}_{3} \mathrm{O}_{4}$. The particle size of manganese oxides is greatly dependent on their preparation conditions. Dimesso et al. [4] claimed that manganese oxides can be prepared by an inert gas condensation technique followed by annealing in air and oxygen at various temperatures. The predominant phase of $\mathrm{MnO}$ and $\mathrm{Mn}_{3} \mathrm{O}_{4}$ are obtained after annealing in air at $400{ }^{\circ} \mathrm{C}$.

Mixed oxides containing transition metal oxides are used to design the catalytic materials to replace noble metal catalysts. Lahousse et al. [1] have found that $\gamma-\mathrm{MnO}_{2}$ and $\mathrm{Pt} / \mathrm{TiO}_{2}$ catalysts measured high catalytic activities as compared to noble metals catalysts.

Mixing manganese with transition metal oxides in many catalytic systems modify the catalytic activity of individual components [5,6]. Mixed oxide materials are active for oxidation-reduction reactions and combustion processes. For example, cobalt-zinc manganites, manganese- $-\mathrm{CeO}_{2}$ mixed oxides and Co-containing mixed oxides prepared from hydrotalcite-like precursors were active catalysts in the reduction of nitrous oxide [7-9]. Also, Co-Mn mixed oxides were found to be active catalysts for oxidation of ethanol [10] and conversion of synthesis gas to light olefins [11]. However, $\mathrm{Ag}-\mathrm{Mn}, \mathrm{Ag}-\mathrm{Co}$ and $\mathrm{Ag}-\mathrm{Ce}$ composite oxides supported on $\mathrm{Al}_{2} \mathrm{O}_{3}$ have been reported as catalysts for oxidation of volatile organic compounds [12]. In a previous study, $\mathrm{Mn}-\mathrm{Cu}$ mixed oxides have been reported to 
be catalytically more active towards ethanol oxidation as compared to individual $\mathrm{Mn}_{2} \mathrm{O}_{3}$ and $\mathrm{CuO}$ [6]. Both copper and manganese mixed oxides catalysts were found to be more active catalysts in many industrial oxidation processes, such as $\mathrm{CO}$ oxidation by $\mathrm{O}_{2}$, combustion of toluene, methanol, ethylene, ammonia, $\mathrm{NO}_{2}$ and other combustion reactions [13-16]. However, $\mathrm{Mn}-\mathrm{Zr}$ mixed oxide samples are active towards dehydrogenation of isopropanol, giving rise to acetone with high selectivity at partial conversion [17].

Hydrogen peroxide and its solutions find use as antiseptic in medicine [18, 19], other applications such as bleach in the textile and paper/pulp industry, in treatment of waste water [20]. However, the literature survey reveals that mixed oxide catalyst is more active in $\mathrm{H}_{2} \mathrm{O}_{2}$ decomposition. These catalysts have attracted much attention of chemists due to their application as low-cost fuel cells, their stability and high activity [21, 22]. The decomposition of hydrogen peroxide in presence of some metal oxides as $\mathrm{LaMnO}_{3}$ at room temperature and nanocrystalline $\mathrm{LaCrO}_{3}$ was investigated by Khetre et al. [23]. They found that the catalytic activity was increased by increasing both the amount of the catalyst and $\mathrm{pH}$. The probable reaction mechanism has been suggested in which an intermediate surface complex is thought to be responsible for the enhancement of the decomposition of hydrogen peroxide.

The present work aimed at studying the effect of $\mathrm{La}_{2} \mathrm{O}_{3^{-}}$ doping of $\mathrm{CoO} / \mathrm{Mn}_{2} \mathrm{O}_{3}$ system prepared by coprecipitation method on its structural, surface and catalytic properties. The techniques employed were XRD, EDX, $\mathrm{N}_{2}$-adsorption isotherms carried out at $-196{ }^{\circ} \mathrm{C}$ and catalytic decomposition of $\mathrm{H}_{2} \mathrm{O}_{2}$ in aqueous solution at $30-50{ }^{\circ} \mathrm{C}$.

\section{Experimental}

\section{Materials}

Equimolar proportions of $\mathrm{CoO} / \mathrm{Mn}_{2} \mathrm{O}_{3}$ were prepared by coprecipitation method of their mixed hydroxides from their nitrates solution using $1 \mathrm{M} \mathrm{NaOH}$ solution at $\mathrm{pH} 8$ and a temperature of $70{ }^{\circ} \mathrm{C}$. The carefully washed precipitate was dried at $110^{\circ} \mathrm{C}$ till constant weight, and then subjected to heating at 300,400 , and $500{ }^{\circ} \mathrm{C}$ for $4 \mathrm{~h}$. Three $\mathrm{La}_{2} \mathrm{O}_{3}$-doped samples were prepared by impregnating a given dry weight of the mixed hydroxides with calculated amount of lanthanum nitrate dissolved in the least amount of distilled water sufficient to make pastes. The pastes were dried at $110{ }^{\circ} \mathrm{C}$ and then calcined at 300,400 and $500{ }^{\circ} \mathrm{C}$ for $4 \mathrm{~h}$. The dopant concentrations in the calcined solids were $0.75,1.5$, and $3 \mathrm{~mol} \% \mathrm{La}_{2} \mathrm{O}_{3}$.

\section{Techniques}

X-ray powder diffractograms of various investigated samples calcined at 300,400 and $500{ }^{\circ} \mathrm{C}$ were determined using a Bruker diffractometer (Bruker D 8 advance target). The patterns were run with copper $K_{\alpha}$ with secondly monochromator $(\lambda=1.5405 \AA)$ at $40 \mathrm{kV}$ and $40 \mathrm{~mA}$. The scanning rate was $0.8^{\circ}$ in $2 \theta \mathrm{min}^{-1}$ for phase identification and line broadening profile analysis, respectively. The crystallite size of the phases present in pure and variously $\mathrm{La}_{2} \mathrm{O}_{3}$-doped solids was determined using the Scherrer equation [24]:

$d=K \lambda / \beta_{1 / 2} \cos \theta$,

where $d$ is the mean crystallite diameter, $\lambda$ is the X-ray wave length of the $\mathrm{X}$-ray beam, $K$ is the Scherrer constant (0.89), $\beta_{1 / 2}$ is the full width at half maximum (FWHM) of the main diffraction peaks of the investigated phases, in radian and $\theta$ is the diffraction angle.

Energy dispersive X-ray analysis (EDX) was carried out on a Hitachi S-800 electron microscope with a Kevex Delta system attached. The parameters were as follows: $-15 \mathrm{kV}$ accelerating voltage, $100 \mathrm{~s}$ accumulation time, $8 \mu \mathrm{m}$ window width. The surface molar composition was determined by the Asa method (Zaf-correction, Gaussian approximation).

Different surface characteristics, namely specific surface area $\left(S_{\mathrm{BET}}\right)$, total pore volume $\left(V_{\mathrm{p}}\right)$, mean pore radius $\left(r^{-}\right)$ and pore volume distribution curves $(\Delta v / \Delta r)$ of various solids were determined from nitrogen adsorption-desorption isotherms measured at $-196{ }^{\circ} \mathrm{C}$ using NOVA Automated Gas sorbometer. Before undertaking such measurements, each sample was degassed under a reduced pressure of $10^{-5}$ Torr for $3 \mathrm{~h}$ at $200{ }^{\circ} \mathrm{C}$. The values of $V_{\mathrm{p}}$ were computed from the relation:

$V_{\mathrm{p}}=15.45 \times 10^{-4} \times V_{\mathrm{st}} \mathrm{cm}^{3} / \mathrm{g}$,

where $V_{\mathrm{st}}$ is the volume of nitrogen adsorbed at $P / P^{0}$ tends to unity. The values of $r^{-}$were determined from the equation:

$r^{-}=\frac{2 V_{\mathrm{p}}}{S_{B E T}} \times 10^{4} \AA$.

The catalytic activities of pure and variously $\mathrm{La}_{2} \mathrm{O}_{3}$ doped solids were determined by studying the decomposition of $\mathrm{H}_{2} \mathrm{O}_{2}$ in their presence at temperatures within $30-50{ }^{\circ} \mathrm{C}$ using 25,50 and $100 \mathrm{mg}$ of a given catalyst sample with $0.5 \mathrm{ml}$ volume of $\mathrm{H}_{2} \mathrm{O}_{2}$ of known concentration diluted to $20 \mathrm{ml}$ with distilled water (initial concentration of $\mathrm{H}_{2}$ $\mathrm{O}_{2}=0.01 \mathrm{~mol} / \mathrm{L}$ ). The reaction kinetics was monitored by measuring the volume of oxygen liberated at different time intervals until no further $\mathrm{O}_{2}$ was liberated. The volume of the liberated oxygen was recalculated under STP. 


\section{Results and discussion}

\section{X-ray investigation of various solids}

$\mathrm{X}$-ray diffractograms of un-doped and variously $\mathrm{La}_{2} \mathrm{O}_{3}$ doped solids calcined at $300-500{ }^{\circ} \mathrm{C}$ were determined from the recorded diffractograms of these solids are illustrated in Figs. 1, 2, 3 for the solids calcined at 300,400 and $500{ }^{\circ} \mathrm{C}$, respectively. The different structural characteristics of the solids investigated are given in Table 1 . Table 1 includes the peak area of the main diffraction lines of different phases present and the crystallite size of $\mathrm{CoMn}_{2} \mathrm{O}_{4}$ phase formed calculated from the Scherrer equation.

Examination of Figs. 1, 2, 3 and Table 1 shows the following: (1) pure and variously $\mathrm{La}_{2} \mathrm{O}_{3}$-doped solids calcined at $300-500{ }^{\circ} \mathrm{C}$ consisted of nano-sized cobalt manganite $\left(\mathrm{Co}_{2} \mathrm{MnO}_{4}\right)$ (02-1061-JCPDS-ICDD, Copyright, 2001) as a major phase together with un-reacted $\mathrm{Co}_{3} \mathrm{O}_{4}$ (42-1467-JCPDS-ICDD, Copyright, 2001) and $\gamma-\mathrm{Mn}_{3} \mathrm{O}_{4}$ (18-0803-JCPDS-ICDD, Copyright, 2001) phases. (2) The peak area of the main diffraction lines of $\mathrm{Co}_{2} \mathrm{MnO}_{4}$ phase decreases progressively by increasing the amount of $\mathrm{La}_{2} \mathrm{O}_{3}$-added in different solids. For example, the peak area of the main diffraction peak of cobalt manganite for the solids calcined at $500{ }^{\circ} \mathrm{C}$ measured 73.5, 55.1, 37.7 and 28.9 (a.u.) for pure sample and those treated with $0.75,1.5$ and $3 \mathrm{~mol} \% \mathrm{La}_{2} \mathrm{O}_{3}$, respectively. (3) The crystallite size of the produced $\mathrm{Co}_{2} \mathrm{MnO}_{4}$ varies between 21.3 and $75.7 \mathrm{~nm}$ depending on the dopant concentration and calcination temperature. (4) The increase in calcination temperature of various solids investigated within $300-500{ }^{\circ} \mathrm{C}$ increased progressively the peak area of the main diffraction line corresponding to the produced $\mathrm{Co}_{2} \mathrm{MnO}_{4}$. (5) No diffraction peak of lanthanum or lanthanum-manganite and

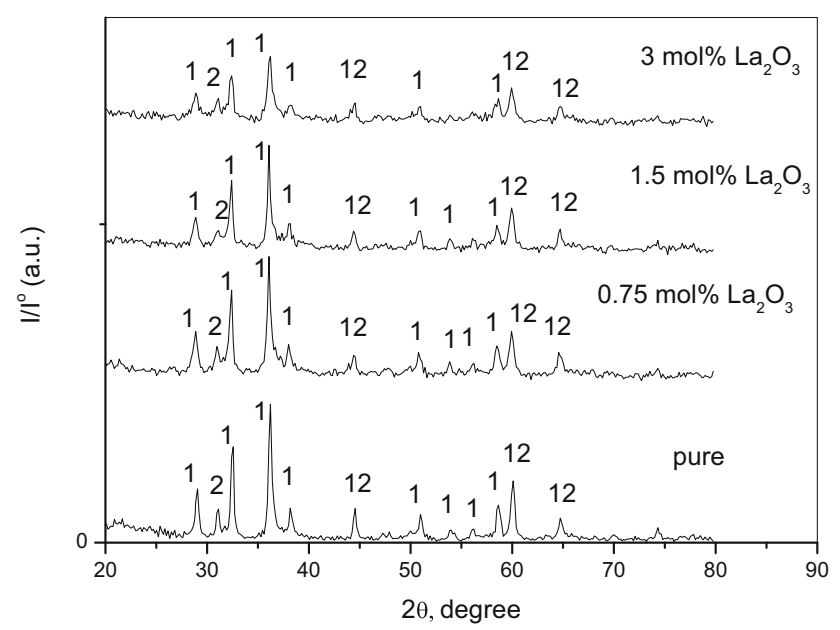

Fig. 1 X-ray diffractograms of pure and variously doped solids calcined at $300{ }^{\circ} \mathrm{C}$. Lines 1 refer to $\mathrm{Co}_{2} \mathrm{MnO}_{4}$, lines 2 refers to $\mathrm{Co}_{3} \mathrm{O}_{4}$

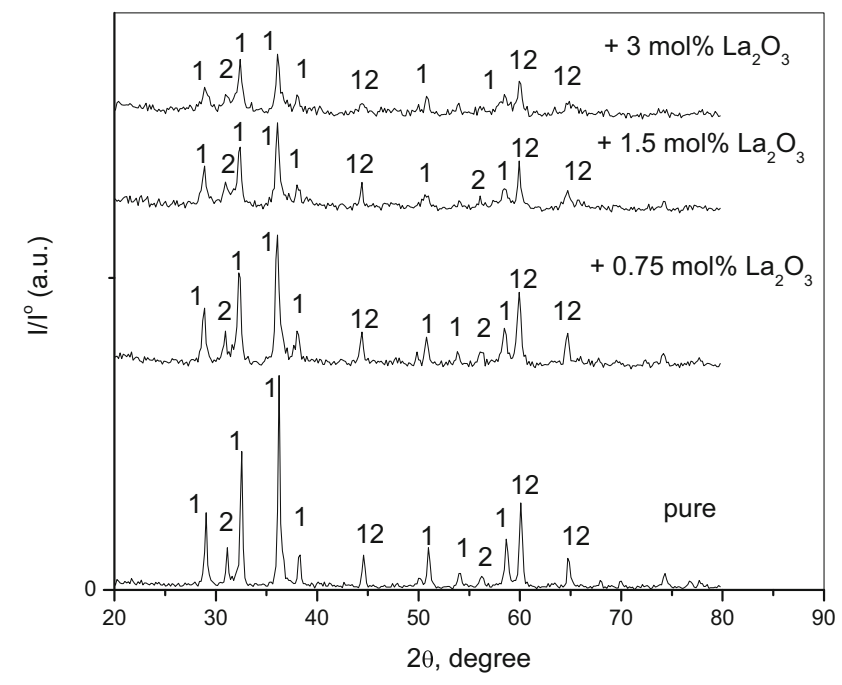

Fig. 2 X-ray diffractograms of pure and variously doped solids calcined at $400{ }^{\circ} \mathrm{C}$. Lines 1 refer to $\mathrm{Co}_{2} \mathrm{MnO}_{4}$, lines 2 refers to $\mathrm{Co}_{3} \mathrm{O}_{4}$

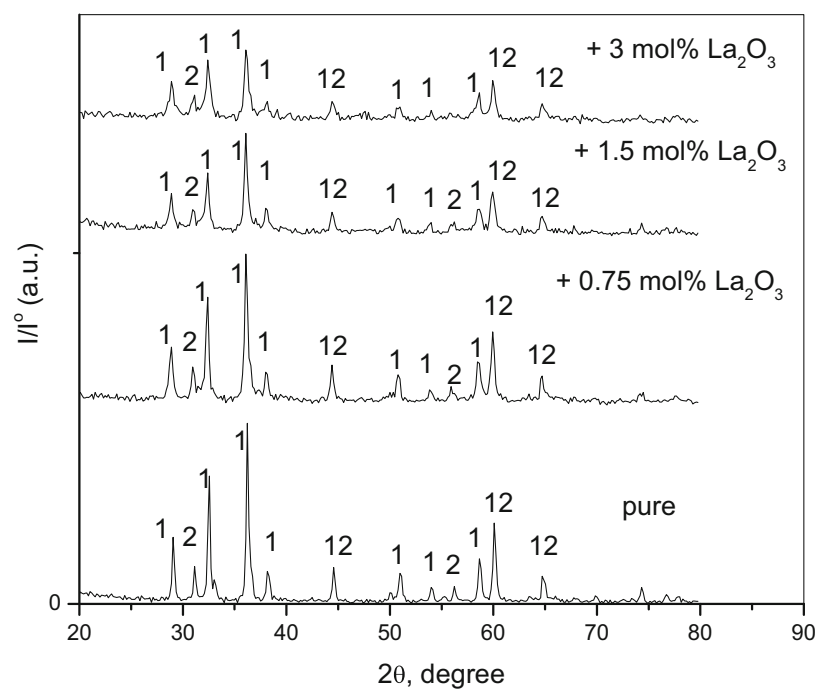

Fig. 3 X-ray diffractograms of pure and variously doped solids calcined at $500{ }^{\circ} \mathrm{C}$. Lines 1 refer to $\mathrm{Co}_{2} \mathrm{MnO}_{4}$, lines 2 refers to $\mathrm{Co}_{3} \mathrm{O}_{4}$

lanthanum-cobaltite composites were detected in the diffractograms. This finding suggested clearly that $\mathrm{La}_{2} \mathrm{O}_{3}$ acted only as a doping agent.

These results show clearly the role of $\mathrm{La}_{2} \mathrm{O}_{3}$ in hindering the solid-solid interaction between cobalt and manganese oxide to yielding cobalt manganite. The increase in calcination temperature within $300-500{ }^{\circ} \mathrm{C}$ stimulated the formation of $\mathrm{Co}_{2} \mathrm{MnO}_{4}$. The formation of $\mathrm{Co}_{2} \mathrm{MnO}_{4}$ took place according to the reaction:

$4 \mathrm{Co}_{3} \mathrm{O}_{4}+3 \mathrm{Mn}_{2} \mathrm{O}_{3} \stackrel{300-500^{\circ} \mathrm{C}}{\rightarrow} 6 \mathrm{Co}_{2} \mathrm{MnO}_{4}+1 / 2 \mathrm{O}_{2}$

The addition of smallest amounts of $\mathrm{La}_{2} \mathrm{O}_{3}(0.75-3 \mathrm{~mol} \%)$ followed by heating at $300-500{ }^{\circ} \mathrm{C}$ hindered $\mathrm{Co}_{2} \mathrm{MnO}_{4}$ formation to an extent proportional to its amount added. 
Table 1 Peak area of different phases present in pure and variously doped $\mathrm{Co}_{3} \mathrm{O}_{4}-\mathrm{Mn}_{3} \mathrm{O}_{4}$ solids calcined at $300-500{ }^{\circ} \mathrm{C}$ and the crystallite size of $\mathrm{Co}_{2} \mathrm{MnO}_{4}$ phase

\begin{tabular}{|c|c|c|c|c|c|}
\hline \multirow[t]{2}{*}{ Solids } & \multirow{2}{*}{$\begin{array}{l}\text { Calcination temperature } \\
\left({ }^{\circ} \mathrm{C}\right)\end{array}$} & \multicolumn{3}{|c|}{ Peak area (a.u.) of diffraction lines of } & \multirow{2}{*}{$\begin{array}{l}\text { Crystallite size (nm) } \\
\mathrm{Co}_{2} \mathrm{MnO}_{4}\end{array}$} \\
\hline & & $\begin{array}{l}\mathrm{Co}_{2} \mathrm{MnO}_{4} \\
\text { phase } \\
2.48 \AA \\
(100 \%)\end{array}$ & $\begin{array}{l}\mathrm{Co}_{3} \mathrm{O}_{4} \\
\text { phase } \\
2.85 \AA \\
(34 \%)\end{array}$ & $\begin{array}{l}\gamma-\mathrm{Mn}_{3} \mathrm{O}_{4} \\
\text { phase } \\
3.08 \AA \\
(90 \%)\end{array}$ & \\
\hline \multirow{3}{*}{$\begin{array}{l}\text { Pure }(0.5 \mathrm{~mol} \mathrm{CoO}+0.5 \mathrm{~mol} \\
\left.\qquad \mathrm{Mn}_{2} \mathrm{O}_{3}\right)\end{array}$} & 300 & 47.5 & 11.2 & 17.8 & 51.3 \\
\hline & 400 & 70.3 & 13.9 & 27 & 59.7 \\
\hline & 500 & 73.5 & 14.5 & 26.5 & 75.7 \\
\hline \multirow[t]{3}{*}{$+0.75 \mathrm{~mol} \% \mathrm{La}_{2} \mathrm{O}_{3}$} & 300 & 39 & 7 & 10.8 & 26.3 \\
\hline & 400 & 45.9 & 11.7 & 20.5 & 27.5 \\
\hline & 500 & 55.1 & 14.3 & 21.3 & 31.5 \\
\hline \multirow[t]{3}{*}{$+1.5 \mathrm{~mol} \% \mathrm{La}_{2} \mathrm{O}_{3}$} & 300 & 31.6 & 11.1 & 15.4 & 28.7 \\
\hline & 400 & 31.7 & 10.8 & 15.4 & 30.4 \\
\hline & 500 & 37.7 & 8.6 & 15.3 & 31.5 \\
\hline \multirow[t]{3}{*}{$+3 \mathrm{~mol}_{2} \mathrm{La}_{2} \mathrm{O}_{3}$} & 300 & 25.2 & 9.3 & 11.6 & 21.3 \\
\hline & 400 & 21.3 & 7.8 & 9.8 & 23.5 \\
\hline & 500 & 28.9 & 9.8 & 15.2 & 30.8 \\
\hline
\end{tabular}

The retardation effect of $\mathrm{La}_{2} \mathrm{O}_{3}$ might be attributed to dissolution of some of $\mathrm{La}_{2} \mathrm{O}_{3}\left(\mathrm{La}^{3+}\right)$ cation in the lattices of $\mathrm{Co}_{3} \mathrm{O}_{4}$ and/or $\mathrm{Mn}_{3} \mathrm{O}_{4}$ assuming that $\mathrm{Co}_{3} \mathrm{O}_{4}$ consisted of (2 $\mathrm{CoO}$ and $\mathrm{Co}_{2} \mathrm{O}_{3}$, i.e., cobalt cations existed in di- and/or tetra-valent states. The dissolution of $\mathrm{La}_{2} \mathrm{O}_{3}$ in $\mathrm{Co}_{3} \mathrm{O}_{4}$ lattices could be simplified adopting Kröger's notations [25] according to:

$$
\begin{aligned}
& \mathrm{La}^{3+}+\mathrm{Co}^{4+}+\mathrm{Co}^{2+} \rightarrow \mathrm{La}\left(\mathrm{Co}^{4+}\right)+\mathrm{Co}^{3+}+1 / 2 \mathrm{O}_{2} \\
& \mathrm{La}^{3+}+\mathrm{Co}^{2+}+1 / 2 \mathrm{O}_{2}+\mathrm{Co}^{4+} \rightarrow \mathrm{La}\left(\mathrm{Co}^{2+}\right)+\mathrm{Co}^{3+},
\end{aligned}
$$

where $\mathrm{La}\left(\mathrm{Co}^{4+}\right)$ is lanthanum cation located in the position of host tetravalent cobalt cation lattice and $\mathrm{La}\left(\mathrm{Co}^{2+}\right)$ is lanthanum cation located in the position of host divalent cobalt lattice cation in $\mathrm{Co}_{3} \mathrm{O}_{4}$. It is clear from Eqs. 1 and 2 that incorporation of $\mathrm{La}^{3+}$ in cobaltic oxide lattice decreased the concentrations of divalent and tetravalent cobalt cations converting them into $\mathrm{Co}^{3+}$ ions. The trivalent cobalt cations did not participate directly in the formation of $\mathrm{CoMn}_{2} \mathrm{O}_{4}$ which involved divalent cobalt and trivalent manganese cations. So, the incorporation of lanthanum cation in $\mathrm{Co}_{3} \mathrm{O}_{4}$ lattice according to mechanism 1 decreased the number of divalent cobalt involved in the formation of $\mathrm{CoMn}_{2} \mathrm{O}_{4}$ phase. Consequently, the retardation of $\mathrm{La}_{2} \mathrm{O}_{3}$ dopant in $\mathrm{CoMn}_{2} \mathrm{O}_{4}$ formation could be understood.

\section{Surface characteristics of various prepared solids}

Nitrogen adsorption-desorption isotherms measured at $-196{ }^{\circ} \mathrm{C}$ were determined for pure and variously $\mathrm{La}_{2} \mathrm{O}_{3}$ doped $\mathrm{Co}_{3} \mathrm{O}_{4} / \mathrm{Mn}_{3} \mathrm{O}_{4}$ solids calcined at 300, 400 and
$500{ }^{\circ} \mathrm{C}$. All isotherms belong to type II of Branuer classification [26] having hysteresis loops of small areas closing at $P / P^{0}$ at about 0.5 . Figure 4 depicts representative $\mathrm{N}_{2}$ adsorption-desorption isotherms measured over pure and variously doped solids calcined at $500{ }^{\circ} \mathrm{C}$. Figure 5 depicts $\Delta v / \Delta r$ curves of various solids calcined at 300 and $500{ }^{\circ} \mathrm{C}$. Analysis of the recorded adsorption-desorption isotherms permitted us to calculate different surface characteristics, namely specific surface area $\left(S_{\mathrm{BET}}\right)$, total pore volume $\left(V_{\mathrm{p}}\right)$ and mean pore radius $\left(r^{-}\right)$. The computed values of $S_{\mathrm{BET}}$, $V_{\mathrm{p}}$ and $r^{-}$are given in Table 2 .

Examination of Table 2 and Fig. 5 shows the following: (1) the $S_{\mathrm{BET}}$ and $V_{\mathrm{p}}$ values of pure and variously doped solids increased progressively by increasing the calcination temperature within $300-500{ }^{\circ} \mathrm{C}$. The increase was, however, more pronounced for pure mixed solids which attained 113 and $295 \%$ for $S_{\mathrm{BET}}$ and $V_{\mathrm{p}}$, respectively [27]. (2) The $r^{-}$ values cited in the last column of Table 2 show that the investigated solids are mesoporous adsorbents measuring $\left(r^{-}\right)$values varying between 30 and $88 \AA$. (3) $\mathrm{La}_{2} \mathrm{O}_{3}$-doping decreased effectively the $S_{\mathrm{BET}}$ to an extent directly proportional to its amount present. The doping process did not affect the $r^{-}$values which remained almost constant for heavily doped sample $\left(3 \mathrm{~mol} \% \mathrm{La}_{2} \mathrm{O}_{3}\right)$. (4) Most of the investigated solids exhibit bimodal pore volume distribution curves except the heavily doped sample $\left(3 \mathrm{~mol} \% \mathrm{La}_{2} \mathrm{O}_{3}\right)$ exhibited tri-modal distribution curves (c.f. Figure 5). The maximum hydraulic pore radius was located at 11.5 and $27.5 \AA$ for pure solids and found at 10 and $23 \AA$ for solids doped by $0.75 \mathrm{~mol} \% \mathrm{La}_{2} \mathrm{O}_{3}$ and 9.5 and $30 \AA$ for solids doped by $1.5 \mathrm{~mol} \% \mathrm{La}_{2} \mathrm{O}_{3}$ and 10,16 and $26 \AA$ for solids doped by $3 \mathrm{~mol} \% \mathrm{La}_{2} \mathrm{O}_{3}$ being calcined at $500{ }^{\circ} \mathrm{C}$. 

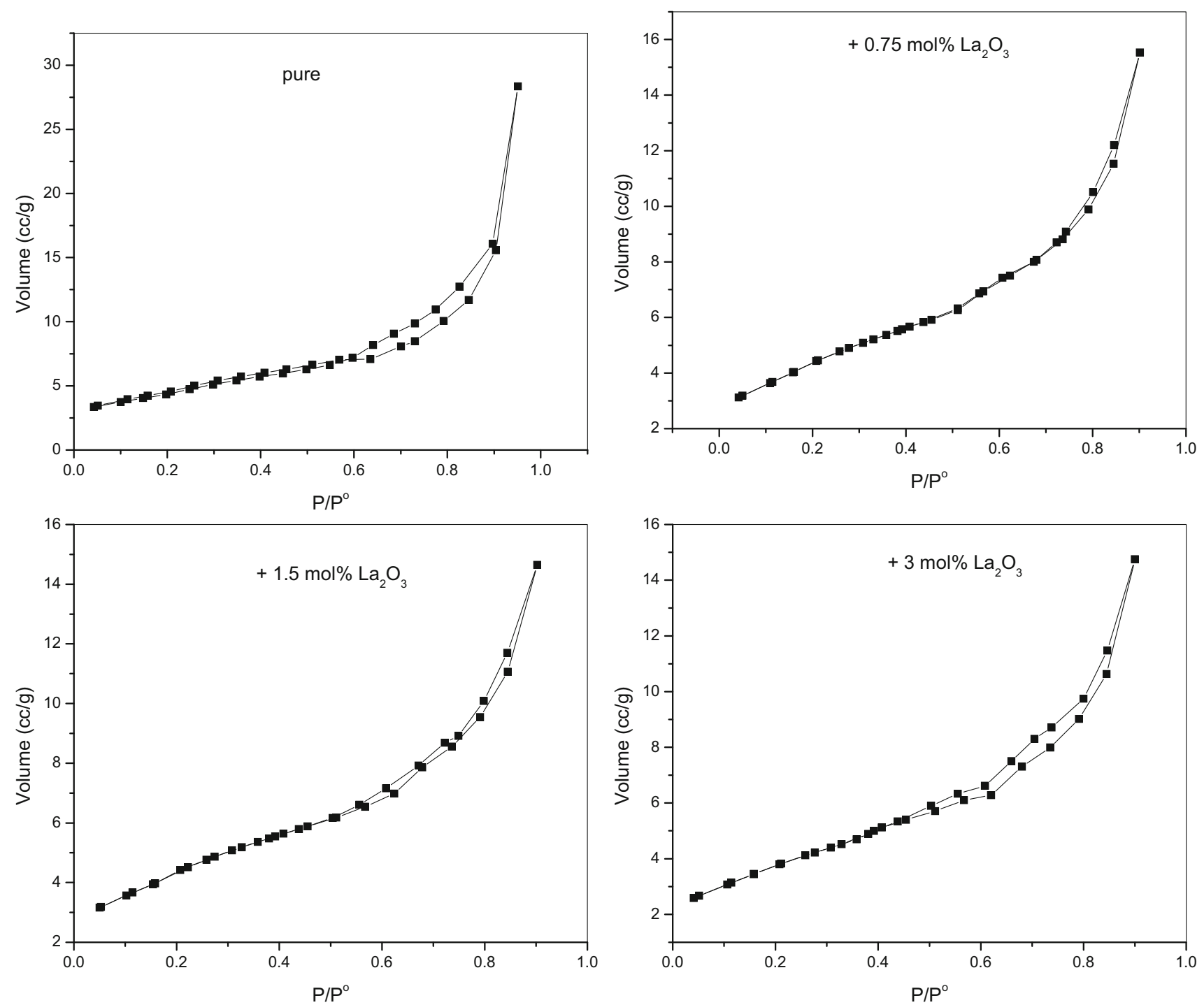

Fig. $4 \mathrm{~N}_{2}$-adsorption-desorption isotherms measured over pure and variously doped solids calcined at $500{ }^{\circ} \mathrm{C}$

These results show clearly the role of $\mathrm{La}_{2} \mathrm{O}_{3}$-doping in modifying the various surface characteristics of the system investigated. Comparison of $\left(r^{-}\right)$values of pure and variously doped solids calcined at $300-500{ }^{\circ} \mathrm{C}$ decreased effectively the calculated $\left(r^{-}\right)$values. This decrease might be followed by an increase in the $S_{\mathrm{BET}}$ values opposite to what was found. So, one might expect that the dopant process decreased the concentration of the narrowest pore located at $11.5 \AA$.

\section{Energy dispersive X-ray analysis of various solids}

EDX investigation of pure and doped solids calcined at $300-500{ }^{\circ} \mathrm{C}$ was determined. The relative atomic abundance of manganese, cobalt, oxygen and lanthanum species present in the uppermost surface layers of the calcined solids is given in Table 3. It is well known that EDX technique supplies an accurate determination of relative atomic concentration of different elements present on their outermost surface layers [28-34]. In fact, this technique (EDX) has been successfully employed in determining the surface composition of a big variety of catalytic systems such as $\mathrm{CuO} / \mathrm{Mn}_{2} \mathrm{O}_{3}$ [28], $\mathrm{CuO} / \mathrm{ZnO}\left[29,31,33\right.$ ], $\mathrm{TiO}_{2} /$ $\mathrm{Al}_{2} \mathrm{O}_{3}$ [30], $\mathrm{CuO} / \mathrm{NiO}$ [32] and $\mathrm{Co}_{3} \mathrm{O}_{4} / \mathrm{Fe}_{2} \mathrm{O}_{3}$ [34]. The thickness of these layers is bigger than those measured by using XPS technique. XPS is a well-known surface-sensitive technique that supplies very accurate relative atomic abundance of cationic and anionic species on the surfaces of investigated solids. Surface and bulk compositions of various solids are given in Table 3. Inspection of the results given in Table 3 reveals the following: (1) the surface composition of pure and variously doped solids is different from those of their bulk. (2) The surface concentration of cobalt species is always smaller than that presents in the 

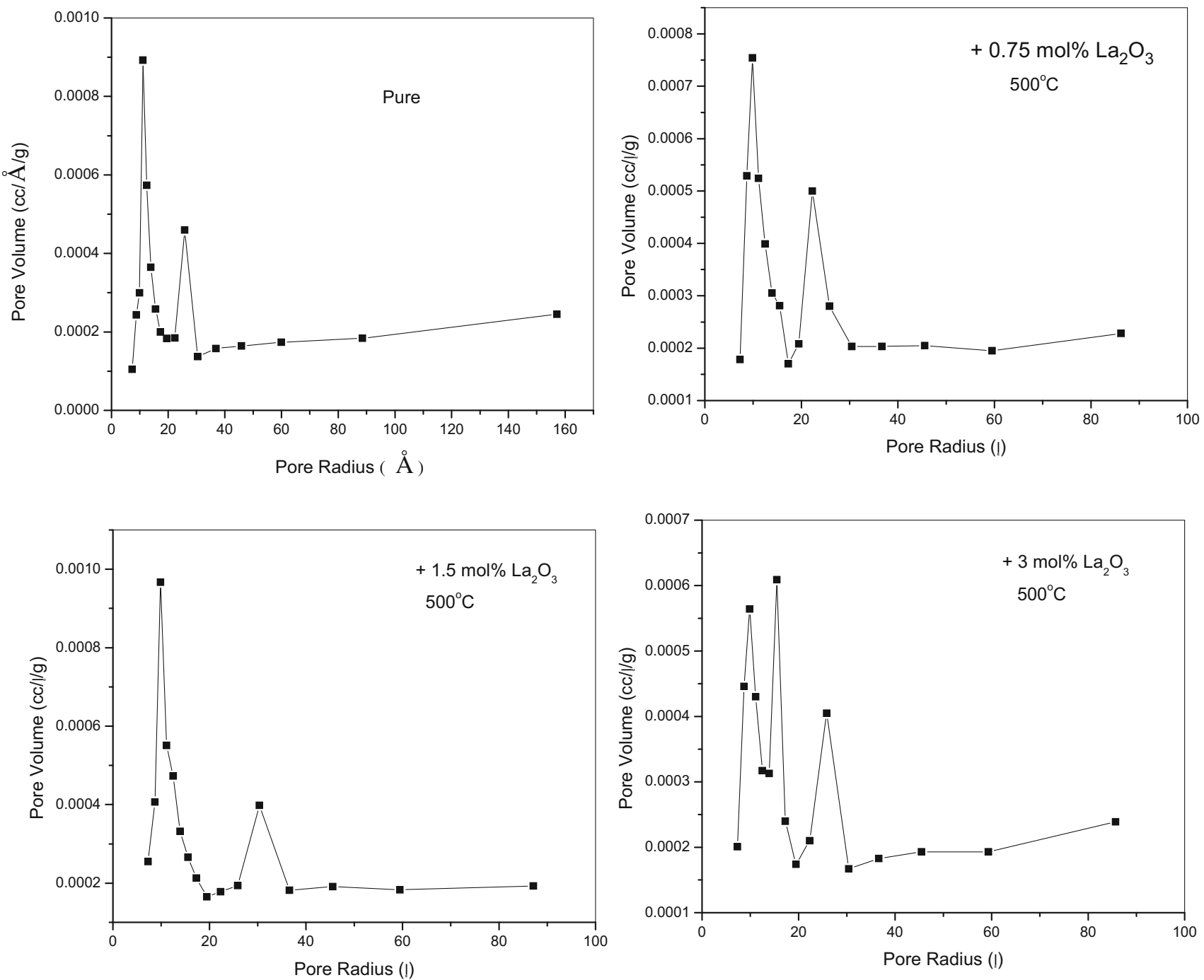

Fig. 5 Pore volume distribution curves $\Delta v / \Delta r$ for pure and variously doped solids calcined at $500{ }^{\circ} \mathrm{C}$

Table 2 Surface characteristics of pure and variously treated solids being calcined at $300-500{ }^{\circ} \mathrm{C}$

\begin{tabular}{lllll}
\hline Solids & $\begin{array}{l}\text { Calcination } \\
\text { temperature }\left({ }^{\circ} \mathrm{C}\right)\end{array}$ & $\begin{array}{l}S_{\mathrm{BET}} \\
\left(\mathrm{m}^{2} / \mathrm{g}\right)\end{array}$ & $\begin{array}{l}\text { Total pore volume } \\
V_{\mathrm{p}}(\mathrm{cc} / \mathrm{g})\end{array}$ & $\begin{array}{l}\text { Mean pore radius } \\
r^{-}(\AA)\end{array}$ \\
\hline Pure $(0.5 \mathrm{~mol} \mathrm{CoO}$ & 300 & 16 & 0.038 & 48 \\
$\left.+0.5 \mathrm{~mol} \mathrm{Mn} \mathrm{O}_{3}\right)$ & 400 & 17 & 0.045 & 52 \\
& 500 & 34 & 0.15 & 88 \\
$+0.75 \mathrm{~mol}^{2} \mathrm{La}_{2} \mathrm{O}_{3}$ & 300 & 13 & 0.021 & 32 \\
& 400 & 14 & 0.022 & 31 \\
$+1.5 \mathrm{~mol} \% \mathrm{La}_{2} \mathrm{O}_{3}$ & 500 & 16 & 0.024 & 30 \\
& 300 & 12 & 0.011 & 18 \\
& 400 & 14 & 0.015 & 21 \\
$+3 \mathrm{~mol} \% \mathrm{La}_{2} \mathrm{O}_{3}$ & 500 & 15 & 0.016 & 32 \\
& 300 & 10 & 0.016 & 33 \\
& 400 & 12 & 0.020 & 33 \\
\hline
\end{tabular}


Table 3 Surface molar composition of pure and variously treated solids determined by EDX

\begin{tabular}{|c|c|c|c|c|c|}
\hline \multirow[t]{2}{*}{ Solid } & \multirow{2}{*}{$\begin{array}{l}\text { Calcination } \\
\text { temperature }\left({ }^{\circ} \mathrm{C}\right)\end{array}$} & \multirow[t]{2}{*}{ Element } & \multicolumn{2}{|c|}{ Atomic abundance (at.\%) } & \multirow{2}{*}{$\begin{array}{l}\text { Mn/Co ratio } \\
\text { (surface) }\end{array}$} \\
\hline & & & Bulk & Surface & \\
\hline \multirow{9}{*}{$\begin{array}{l}\text { Pure }(0.5 \mathrm{~mol} \\
\mathrm{CoO}+0.5 \mathrm{~mol} \\
\left.\mathrm{Mn}_{2} \mathrm{O}_{3}\right)\end{array}$} & \multirow[t]{3}{*}{300} & $\mathrm{Mn}$ & 28.57 & 37.0 & \multirow[t]{3}{*}{33.6} \\
\hline & & Co & 14.29 & 1.1 & \\
\hline & & $\mathrm{O}$ & 57.14 & 62.0 & \\
\hline & \multirow[t]{3}{*}{400} & $\mathrm{Mn}$ & 28.57 & 38.6 & \multirow[t]{3}{*}{35.1} \\
\hline & & $\mathrm{Co}$ & 14.29 & 1.1 & \\
\hline & & $\mathrm{O}$ & 57.14 & 60.3 & \\
\hline & \multirow[t]{3}{*}{500} & Mn & 28.57 & 56.0 & \multirow[t]{3}{*}{37.3} \\
\hline & & Co & 14.29 & 1.5 & \\
\hline & & $\mathrm{O}$ & 57.14 & 42.5 & \\
\hline \multirow[t]{12}{*}{$+0.75 \mathrm{~mol} \% \mathrm{La}_{2} \mathrm{O}_{3}$} & \multirow[t]{4}{*}{300} & Mn & 28.39 & 38.3 & \multirow[t]{4}{*}{47.9} \\
\hline & & Co & 14.19 & 0.8 & \\
\hline & & $\mathrm{O}$ & 57.21 & 60.64 & \\
\hline & & $\mathrm{La}$ & 0.21 & 0.26 & \\
\hline & \multirow[t]{4}{*}{400} & Mn & 28.39 & 48.2 & \multirow[t]{4}{*}{53.5} \\
\hline & & Co & 14.19 & 0.9 & \\
\hline & & $\mathrm{O}$ & 57.21 & 50.54 & \\
\hline & & $\mathrm{La}$ & 0.21 & 0.36 & \\
\hline & \multirow[t]{4}{*}{500} & $\mathrm{Mn}$ & 28.39 & 63.3 & \multirow[t]{4}{*}{70.3} \\
\hline & & Co & 14.19 & 0.9 & \\
\hline & & $\mathrm{O}$ & 57.21 & 35.44 & \\
\hline & & $\mathrm{La}$ & 0.21 & 0.4 & \\
\hline \multirow[t]{12}{*}{$+1.5 \mathrm{~mol} \% \mathrm{La}_{2} \mathrm{O}_{3}$} & \multirow[t]{4}{*}{300} & $\mathrm{Mn}$ & 28.21 & 38.0 & \multirow[t]{4}{*}{46.5} \\
\hline & & $\mathrm{Co}$ & 14.11 & 0.8 & \\
\hline & & $\mathrm{O}$ & 57.26 & 60.74 & \\
\hline & & $\mathrm{La}$ & 0.42 & 0.46 & \\
\hline & \multirow[t]{4}{*}{400} & $\mathrm{Mn}$ & 28.21 & 38.9 & 47.4 \\
\hline & & $\mathrm{Co}$ & 14.11 & 0.82 & \\
\hline & & $\mathrm{O}$ & 57.26 & 59.74 & \\
\hline & & $\mathrm{La}$ & 0.42 & 0.54 & \\
\hline & 500 & $\mathrm{Mn}$ & 28.21 & 42.2 & 48.0 \\
\hline & & $\mathrm{Co}$ & 14.11 & 0.88 & \\
\hline & & $\mathrm{O}$ & 57.26 & 56.34 & \\
\hline & & $\mathrm{La}$ & 0.42 & 0.58 & \\
\hline$+3 \mathrm{~mol} \% \mathrm{La}_{2} \mathrm{O}_{3}$ & 300 & Mn & 27.85 & 37.6 & 41.8 \\
\hline & & $\mathrm{Co}$ & 13.93 & 0.9 & \\
\hline & & $\mathrm{O}$ & 57.38 & 60.4 & \\
\hline & & $\mathrm{La}$ & 0.84 & 1.1 & \\
\hline & 400 & $\mathrm{Mn}$ & 27.85 & 38.6 & 42.0 \\
\hline & & Co & 13.93 & 0.92 & \\
\hline & & $\mathrm{O}$ & 57.38 & 59.28 & \\
\hline & & $\mathrm{La}$ & 0.84 & 1.2 & \\
\hline & 500 & $\mathrm{Mn}$ & 27.85 & 40.9 & 43.1 \\
\hline & & Co & 13.93 & 0.95 & \\
\hline & & $\mathrm{O}$ & 57.38 & 56.95 & \\
\hline & & $\mathrm{La}$ & 0.84 & 1.2 & \\
\hline
\end{tabular}


bulk of pure and variously doped solids. (3) The concentration of surface manganese was several folds that of cobalt. This finding might suggest that cobalt hydroxide was precipitated much earlier than manganese hydroxides. This conclusion seems logical because of the significant difference between the values of the solubility products of $\mathrm{Co}(\mathrm{OH})_{3}$ and $\mathrm{Mn}(\mathrm{OH})_{2}$ which measured $5.9 \times 10^{-15}$ and $1.6 \times 10^{-44}$, respectively. (4) Lanthanum species present in the uppermost surface layers of all doped solids calcined at temperature within $300-500{ }^{\circ} \mathrm{C}$ is bigger than the amount present in the bulk of solids. This finding is expected because all doped solids were prepared by wet impregnation method [35, 36]. Furthermore, the surface concentration of lanthanum increases by increasing the calcination temperature of the doped solids. (5) The addition of the smallest amount of $\mathrm{La}_{2} \mathrm{O}_{3}(0.75 \mathrm{~mol} \%)$ much increased the surface concentration of manganese present in all solids calcined at $300-500{ }^{\circ} \mathrm{C}$. The increase in surface concentration of manganese species attained 4, 25 and $13 \%$ for the solids calcined at 300,400 and $500{ }^{\circ} \mathrm{C}$, respectively. The increase of the dopant concentration above $0.75 \mathrm{~mol} \% \mathrm{La}_{2} \mathrm{O}_{3}$ decreased the surface concentration of manganese which still remained bigger than that measured for the un-doped samples calcined at the same temperatures.

It is well known that manganese species present in the uppermost surface layers in pure and doped solids are considered as the most catalytically active constituent involved in $\mathrm{H}_{2} \mathrm{O}_{2}$-decomposition. This assumption is based on the possible presence of manganese cations in different oxidation states varying between di- and hepta-valence states leading to a significant increase in the concentration of manganese ion pairs participating in the catalytic decomposition process. So, the bigger the surface concentration of manganese the bigger will be the concentration of the most catalytically active constituent and the bigger the catalytic activity. This speculation will be confirmed in the next section of the present work dealing with the catalytic decomposition of $\mathrm{H}_{2} \mathrm{O}_{2}$ on pure and variously $\mathrm{La}_{2} \mathrm{O}_{3}$-doped solids calcined at $300-500{ }^{\circ} \mathrm{C}$.

\section{Catalytic activity of pure and variously doped solids}

The catalytic decomposition of $\mathrm{H}_{2} \mathrm{O}_{2}$ in aqueous solution was studied at 30,40 and $50{ }^{\circ} \mathrm{C}$ over pure and variously doped solids precalcined at 300,400 and $500{ }^{\circ} \mathrm{C}$. Firstorder kinetics was observed in all cases. In fact, straight line was found upon plotting $\ln a / a-x$ against the time intervals $t$, where $a$ is the initial concentration of $\mathrm{H}_{2} \mathrm{O}_{2}$ and $a-x$ is its concentration at time $t$. The slopes $(d \ln a / a-x /$ $\mathrm{d} t)$ of plots determine the reaction rate constant $(k)$ for the reaction conducted at a given temperature over a given catalyst sample. The reaction kinetics were monitored using

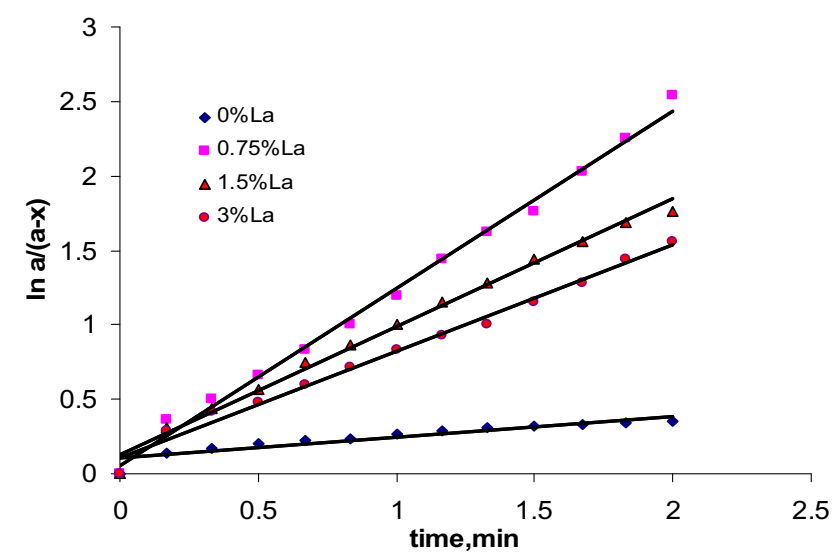

Fig. 6 First-order plots for catalytic decomposition of $\mathrm{H}_{2} \mathrm{O}_{2}$ at $50{ }^{\circ} \mathrm{C}$, over pure and variously doped solids calcined at $500{ }^{\circ} \mathrm{C}$

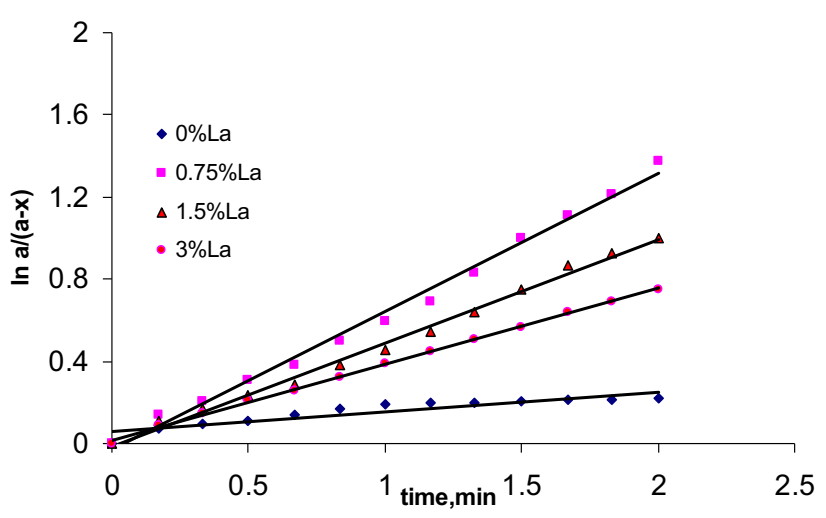

Fig. 7 First-order plots for catalytic decomposition of $\mathrm{H}_{2} \mathrm{O}_{2}$ at $50{ }^{\circ} \mathrm{C}$, over pure and variously doped solids calcined at $300{ }^{\circ} \mathrm{C}$

25,50 and $100 \mathrm{mg}$ of catalyst sample. The results, not given, showed that $k$ value increases linearly by increasing the catalyst mass indicating the absence of any possible solid gas diffusion of liberated oxygen. Figures 6 and 7 depict representative first-order plots of the catalyzed reaction conducted at 30 and $50{ }^{\circ} \mathrm{C}$ over pure and variously $\mathrm{La}_{2} \mathrm{O}_{3}$-doped solids pre-calcined at 300 and $500{ }^{\circ} \mathrm{C}$, respectively. The values of the reaction rate constant per unit mass for the reaction carried out at 30,40 and $50{ }^{\circ} \mathrm{C}$ were calculated from the slope of the first-order plots. Table 4 includes only the computed values of $k_{50}{ }^{\circ} \mathrm{C}$. Inspection of Table 4 reveals the following: (1) the catalytic activity, expressed as reaction rate constant per unit mass, measured for pure and variously doped solids increased by increasing the calcination temperatures of all solids investigated calcined at $300-500{ }^{\circ} \mathrm{C}$. (2) The presence of the smallest amount of $\mathrm{La}_{2} \mathrm{O}_{3}(0.75 \mathrm{~mol} \%)$ increased considerably the $(k)$ values. The increase reached about $10^{3}$-fold for the catalytic reaction carried out at 30 and $50{ }^{\circ} \mathrm{C}$. So, the comparison between the role of $\mathrm{ZrO}_{2}$, as shown in our 
Table 4 Reaction rate constant per gram catalyst, $k_{50^{\circ} \mathrm{C}}^{*}\left(\mathrm{~min}^{-1}\right.$ $\left.\mathrm{g}^{-1}\right) \times 10^{3}$ of catalytic decomposition of $\mathrm{H}_{2} \mathrm{O}_{2}$, activation energy $(\Delta E)$ for the catalytic reaction carried out at $50{ }^{\circ} \mathrm{C}$ over pure and variously $\mathrm{La}_{2} \mathrm{O}_{3}$-doped solids calcined at $300-500{ }^{\circ} \mathrm{C}$

\begin{tabular}{llll}
\hline Solid & $\begin{array}{l}\text { Calcination } \\
\text { temperature } \\
\left({ }^{\circ} \mathrm{C}\right)\end{array}$ & $\begin{array}{l}k_{50^{\circ} \mathrm{C}}^{*} \\
\left(\mathrm{~min}^{-1} \mathrm{~g}^{-1}\right)\end{array}$ & $\begin{array}{l}\Delta E \times 103 \\
\left.(\mathrm{~kJ} \mathrm{~mol})^{-1}\right)\end{array}$ \\
\hline Pure $(0.5 \mathrm{~mol}$ & 300 & 1.24 & 5.2 \\
$\mathrm{CoO}+0.5 \mathrm{~mol}$ & 400 & 1.4 & \\
$\left.\mathrm{Mn}_{2} \mathrm{O}_{3}\right)$ & 500 & 1.66 & \\
$+0.75 \mathrm{~mol} \% \mathrm{La}_{2} \mathrm{O}_{3}$ & 300 & 13.6 & 1.5 \\
& 400 & 20.0 & \\
$+1.5 \mathrm{~mol} \% \mathrm{La}_{2} \mathrm{O}_{3}$ & 300 & 22.4 & \\
& 400 & 10.2 & 2.0 \\
& 500 & 14.0 & \\
$+3 \mathrm{~mol} \% \mathrm{La}_{2} \mathrm{O}_{3}$ & 300 & 16.4 & \\
& 400 & 7.2 & 2.7 \\
& 500 & 12.0 & \\
\hline
\end{tabular}

previous studied [27], and $\mathrm{La}_{2} \mathrm{O}_{3}$-doping of $\mathrm{Co}_{3} \mathrm{O}_{4}-\mathrm{Mn}_{3} \mathrm{O}_{4}$ system showed clearly that the increase in the catalytic activity due to the doping process was much more pronounced by doping with $\mathrm{La}_{2} \mathrm{O}_{3}$ as compared to $\mathrm{ZrO}_{2}$-doping [27]. (3) Increasing the dopant concentration above $0.75 \mathrm{~mol} \%$ decreased the catalytic activity to an extent proportional to the amount of $\mathrm{La}_{2} \mathrm{O}_{3}$ added. (4) The observed increase in the catalytic activity of pure and variously doped solids by increasing their calcination temperature within $300-500{ }^{\circ} \mathrm{C}$ might be attributed to the observed increase in surface concentration of manganese species (considered as the most catalytically active constituent) and the observed increase in the specific surface areas (c.f. Tables 2, 3). (5) The observed significant increase in the catalytic activity due to doping with $0.75 \mathrm{~mol} \% \mathrm{La}_{2} \mathrm{O}_{3}$ could be also attributed to the observed decrease in the crystallite size of $\mathrm{Co}_{2} \mathrm{MnO}_{4}$ phase (c.f. Table 1). (6) The decrease in the catalytic activity of the heavily doped solids might result from the observed increase in the crystallite size of $\mathrm{Co}_{2} \mathrm{MnO}_{4}$ (the major phase present in pure and doped solids) and also due to the observed decrease in surface concentration of manganese species besides the significant decrease in the $S_{\mathrm{BET}}$ (c.f. Tables $1,2,3$ ).

In order to throw more light about the role of both calcination temperature and dopant concentration $\left(\mathrm{La}_{2} \mathrm{O}_{3}\right)$ in the mechanism of the catalyzed reaction the activation energy of which $(\Delta E)$ was determined for pure and doped solids calcined at $300-500{ }^{\circ} \mathrm{C} . \Delta E$ values were calculated from the values of $k$ measured for the reaction carried out at 30,40 and $50{ }^{\circ} \mathrm{C}$ by direct application of the Arrhenius equation. The computed $\Delta E$ values are given in Table 4 . Examination of Table 4 shows that $\Delta E$ values for pure and variously doped solids decreased progressively as a function of dopant concentration. This trend ran parallel to observed increase in the catalytic activity, expressed as $k_{50}{ }^{\circ} \mathrm{C}$ values (c.f. Table 4). This finding expresses the observed increase in the catalytic activity of sample of $0.75 \mathrm{~mol} \% \mathrm{La}_{2} \mathrm{O} 3$-doping. On the other hand, increasing the dopant concentration above this limit increased $\Delta E$ values which remained almost smaller than $\Delta E$ values measured for the pure catalyst samples.

\section{Conclusions}

The main conclusions derived from the results obtained can be summarized as follows:

1. The role of $\mathrm{La}_{2} \mathrm{O}_{3}$-doping on structural, textural, surface composition and catalytic activity was investigated.

2. The prepared mixed solids consisted of nano-sized $\mathrm{Co}_{2} \mathrm{MnO}_{4}$ as a major phase together with un-reacted portion of $\mathrm{Co}_{3} \mathrm{O}_{4}$ and $\gamma-\mathrm{Mn}_{3} \mathrm{O}_{4}$.

3. Doping with $\mathrm{La}_{2} \mathrm{O}_{3}(0.75 \mathrm{~mol} \%)$ much increased both surface molar ratio of $\mathrm{Mn} / \mathrm{Co}$ with $(0.75 \mathrm{~mol} \%)$ about $88 \%$ with subsequent increase in the catalytic activity more than 12 -fold.

4. The apparent activation energy of the catalyzed reaction measured 5.2, $1.5,2.0$ and $2.7 \mathrm{~kJ} / \mathrm{mol}$ for the un-doped and catalyst doped with $0.75,1.5$ and $3 \mathrm{~mol} \% \mathrm{La}_{2} \mathrm{O}_{3}$.

Open Access This article is distributed under the terms of the Creative Commons Attribution 4.0 International License (http://crea tivecommons.org/licenses/by/4.0/), which permits unrestricted use, distribution, and reproduction in any medium, provided you give appropriate credit to the original author(s) and the source, provide a link to the Creative Commons license, and indicate if changes were made.

\section{References}

1. Lahousse C, Bernier A, Grange P, Delmon B, Papaefthimiou P, Ioannides T, Very Kios X (1998) Evaluation of $\gamma-\mathrm{MnO}_{2}$ as a VOC removal catalyst: comparison with a noble metal catalyst. J Catal 178:214-225

2. Baldi M, Escribano VS, Amores JMG, Milella F, Busca G (1998) Characterization of manganese and iron oxides as combustion catalysts for propane and propene. Appl Catal B 17:L175

3. Chen C-Y, Lin C-K, Tsai N-H, Tsay C-Y, Lee P-Y, Chen G-S (2008) Characterization of nanocrystalline manganese oxide powder prepared by inert gas condensation. Ceram Int 34:1661

4. Dimesso L, Heider I, Hahn H (1999) Synthesis of nanocrystalline Mn-oxides by gas condensation. Solid State Ion 123:39-46

5. Li W, Lin Y, Zhang Y (2003) Promoting effect of water vapor on catalytic oxidation of methane over cobalt, manganese mixed oxides. Catal Today 83:239-245

6. Morales MR, Barbero BP, Cadús LE (2006) Total oxidation of ethanol and propane over $\mathrm{Mn}-\mathrm{Cu}$ mixed oxide catalysts. Appl Catal B 67:229 
7. Fierro G, Jacono ML, Inversi M, Dragone R, Ferraris G (2001) Preparation, characterization and catalytic activity of Co-Znbased manganites obtained from carbonate precursors. Appl Catal B. $30: 173$

8. Chmielarz L, Kustrowski P, Rafalska-Lasocha A, Majda D, Dziembaj R (2002) Catalytic activity of $\mathrm{Co}-\mathrm{Mg}-\mathrm{Al}, \mathrm{Cu}-\mathrm{Mg}-\mathrm{Al}$ and $\mathrm{Cu}-\mathrm{Co}-\mathrm{Mg}-\mathrm{Al}$ mixed oxides derived from hydrotalcites in SCR of NO with ammonia. Appl Catal B 35:195

9. Qi G, Yang RT, Change R (2004) $\mathrm{MnOx}-\mathrm{CeO} 2$ mixed oxides prepared by co-precipitation for selective catalytic reduction of NO with NH3 at low temperatures. Appl Catal B. 51:93

10. Kovanda F, Rojka T, Dobešová J, Machovič V, Bezdička P, Obalová L, Grygar T (2006) Mixed oxides obtained from Co and Mn containing layered double hydroxides: Preparation, characterization, and catalytic properties. J Solid State Chem 179:812

11. Mirzaei AA, Faizi M, Habibpour R (2006) Effect of preparation conditions on the catalytic performance of cobalt manganese oxide catalysts for conversion of synthesis gas to light olefins. Appl Catal A: Gen 306:98-107

12. Luo M-F, Yuan X-X, Zheng X-M (1998) Catalyst characterization and activity of $\mathrm{Ag}-\mathrm{Mn}, \mathrm{Ag}-\mathrm{Co}$ and $\mathrm{Ag}-\mathrm{Ce}$ composite oxides for oxidation of volatile organic compounds. Appl Catal A: Gen 175:121-129

13. Liu Y, Luo MF, Wei ZB, Xin Q, Ying PL, Li C (2001) Catalytic oxidation of chlorobenzene on supported manganese oxide catalysts. Appl Catal B. 29(1):61

14. Ferrandon M, Bjornbom E (2001) Hydrothermal stabilization by lanthanum of mixed metal oxides and noble metal catalysts for volatile organic compound removal. J Catal 200(1):148-159

15. Alvarez-Galvan MC, O'Shea VADP, Fierro JLG, Arias PL (2003) Alumina-supported manganese- and manganese-palladium oxide catalysts for VOCs combustion. Catal Commun 4(5):223-228

16. Zimowska M, Michalik-Zym A, Janik R, Machej T, Gurgul J, Socha RP, Podobiński J, Serwicka EM (2007) Catalytic combustion of toluene over mixed $\mathrm{Cu}-\mathrm{Mn}$ oxides. Catal Today 119:321

17. López EF, Escribano VS, Resini C, Gallardo-Amores JM, Busca G (2001) A study of coprecipitated $\mathrm{Mn}-\mathrm{Zr}$ oxides and their behaviour as oxidation catalysts. Appl Catal B 29:251

18. Khetre SM, Jadhav HV, Bangale SV, Jagdale PN, Bamane SR (2011) Use of mixed metal oxide as a catalyst in the decomposition of hydrogen peroxide. Ind J Chem 2(2):252-259

19. Shivankar VS, Thakkar NV (2006) Chiral mixed ligand Co (II) and Ni (II) complexes: synthesis and biological activity. Ind J Chem 46A:382-387

20. Wood A (2004) Life after ACC: little change for most firms' EH\&S efforts. Chem Week 166:27

21. Afsin B, Roberts MW (1992) Surface structure and the instability of the formate overlayer at a $\mathrm{Pb}(110)$ surface. Catal Lett 13(3):277-282
22. Kga Y, Oho Y, Tsukanoto K, Nakajima T (1990) Relationships between the gas permeabilities and the microstructures of plasma sprayed oxide layers. Solid State Ion 40/41:1000

23. Khetre SM, Jadhav HV, Bangale SV, Jagdale PN, Bamane SR (2011) Synthesis, characterization and hydrophilic properties of nanocrystalline $\mathrm{ZnCo}_{2} \mathrm{O}_{4}$ oxide by combustion route. Der Chemica Sinica 2(4):303-311

24. Cullity BD (1978) Publishing Cos, 2nd edn. Addison-Wesley, Reading

25. Kröger FA (1964) Chemistry of imperfect crystals. North-Holland, Amsterdam

26. Rouquerol F, Rouquerol J, Sing K (1999) Adsorption by powders and porous solids: principles, methodology and applications. Academic Press, San Diego

27. Ibrahim SM, Badawy AA, El-Shobaky GA, Mohamed HA (2014) Structural, surface and catalytic properties of pure and $\mathrm{ZrO} 2-$ doped nanosized cobalt-manganese mixed oxides. Can J Chem Eng 92:676-684

28. El-Shobaky GA, El-Shobaky HG, Badawy AA, Fahmy YM (2011) Physicochemical, surface and catalytic properties of nanosized copper and manganese oxides supported on cordierite. Appl Catal A: Gen 409-410:234

29. El-Shobaky GA, Hassan HMA, Yehia NS, Badawy AA (2010) Effect of CeO2-doping on surface and catalytic properties of $\mathrm{CuO}-\mathrm{ZnO}$ system. J Non-Cryst Solids 356:32-38

30. El All SA, El-Shobaky GA (2009) Structural and electrical properties of $\gamma$-irradiated TiO2/A12O3 composite prepared by sol-gel method. J Alloys Compd 479:91-96

31. El-Shobaky GA, Yehia NS, Hassan HMA, Badawy AA (2009) Catalytic oxidation of $\mathrm{CO}$ by $\mathrm{O} 2$ over nanosized $\mathrm{CuO}-\mathrm{ZnO}$ system prepared under various conditions. Can J Chem Eng 87:792-800

32. El-Shobaky GA, Radwan NRE, El-Shall MS, Turky AM, Hassan HMA (2009) Physicochemical, surface and catalytic properties of nanocrystalline $\mathrm{CuO}-\mathrm{NiO}$ system as being influenced by doping with $\mathrm{La}_{2} \mathrm{O}_{3}$. Colloids Surf A: Physicochem Eng Asp 345:147-154

33. El-Shobaky GA, Yehia NS, El-Hendawy AA, Abo-Elenin RMM, Badawy AA (2009) Effects of preparation conditions on surface and catalytic properties of copper and zinc mixed oxides system. Open Catal J 2:45-53

34. Fagal GA, Badawy AA, Hassan NA, El-Shobaky GA (2012) Effect of $\mathrm{La}_{2} \mathrm{O}_{3}$-treatment on textural and solid-solid interactions in ferric/cobaltic oxides system. J Solid State Chem 194:162-167

35. Radwan NRE, Fagal GA, El-Shobaky GA (2001) Effects of $\mathrm{CeO}_{2}$-doping on surface and catalytic properties of $\mathrm{Cu}_{\mathrm{O}} / \mathrm{Al}_{2} \mathrm{O}_{3}$ solids. Colloids Surf A 178:277

36. El-Shobaky GA, Fagal GA, Mokhtar M (1997) Effect of ZnO on surface and catalytic properties of $\mathrm{CuOA} 2 \mathrm{O} 3$ system. Appl Catal A: Gen 155:167 